\title{
Managers' Incentives for Issuing Cash flow Forecasts
}

\author{
Suzan Abed \\ Applied Science University \\ Clare Roberts \\ University of Aberdeen \\ Khaled Hussainey \\ Plymouth University \\ Ain Shams University
}

Accepted for publication at

International Journal of Accounting, Auditing and Performance Evaluation

\begin{abstract}
This study examines a recent change in voluntary disclosure by investigating the issuance of management cash flow forecasts for a sample of 690 UK non-financial firm-year observations which are drawn from the top 500 UK listed firms by total market capitalization as listed by Financial Times on 30 March 2007. Automated content analysis is used to search for cash flow forecasts in annual reports narratives using QSR NVivo 8. The results of regression analysis provide support for institutional theory that companies try to imitate the disclosure practices of other companies in the same industry. Also, the results document that operating cash flow, industry behaviour, cross-listing, and company size are positively and significantly related to disclosure of cash flow forecasts, whereas performance and competition rate are negatively and significantly related to disclosure of cash flow forecasts. However, the results fail to find any significant relationship between normative or coercive isomorphism proxies and disclosure of cash flow forecasts.
\end{abstract}

Keywords: Narrative disclosure, Cash flow forecasts, Industry behaviour, Imitation, Leadership, mimetic isomorphism, normative isomorphism, coercive isomorphism, automated content analysis, institutional theory, forward-looking information, panel data, QSR NVivo 8. 


\section{Introduction}

Recent years have seen major changes in financial reporting with reporting becoming increasingly user driven rather than producer driven (Beattie, 2000). In other words, financial reporting is not only about the presentation of historical financial statements and related notes, but it is also about the discussion and explanation of the company's activities and future prospects through the use of narrative sections. This has led to significant increases in the disclosure of information including the disclosure of cash flow forecasts although the specific determinants of such disclosure practices remain unclear.

Previous studies examined the determinants of forward looking information based primarily on propositions provided by agency or information asymmetry theories (e.g., Clarkson et al., 1994, 1999; Cahan and Hossain, 1996; Johnson et al., 2001; Robb et al., 2001; Kent and Ung, 2003; Vanstraelen et al., 2003; Hossain et al., 2005; Celik et al., 2006; Lim et al., 2007; Bozzolan and Mazzola, 2007). However, institutional theory has begun to focus more directly on institutional phenomena within organisations (Moll et al., 2006). Specifically, it argues that organisations could be influenced by cognitive, normative, and regulative structures and activities external to the firm which may provide consistent explanations of disclosure practices (Scott, 1995).

Based on this proposition, determinants of cash flow forecasts information are likely to be subject to two types of influence: company specific information asymmetry or agency characteristics (Healy and Palepu, 2001) and sector, country or market wide institutional factors (DiMaggio and Powell, 1991). Thus, a multi-theoretical lens based on both information asymmetry and institutional theories is used in this study in order to identify potentially new determinants of the voluntary disclosure of cash flow forecasts over the period of change in UK Operating and Financial Review (OFR) regulation from 2004-2006. This time window incorporates the period from 1 January 2004 to 31 March 2005, a period free of regulation, mandatory regulation from 1 April 2005 to 12 January 2006, and another period of voluntary disclosure in the rest of 2006. 
Our paper makes a major contribution to the literature on cash flow forecasts disclosure. It identifies the main managers' incentives for using these forecasts. In particular, it examines the degree to which institutional and information asymmetry variables drive managers to issue these forecasts. Exploring the impact of the change of the OFR regulation on levels of cash flow forecasts is a unique feature of this paper. The paper makes a secondary contribution in terms of the research deign. We use QSR NVivo (8) to text-search a large-scale sample of annual reports over a three-year period. This helps us to automatically identify the number of sentences that are related to cash follow forecasts disclosure with low cost and effort.

The rest of this paper is organised as follows: Section 2 reviews previous studies and outlines the study's hypotheses Section 3 describes the research design. Section 4 presents the empirical results. Section 5 concludes and suggests line for further research.

\section{Literature Review and Hypotheses Development}

Previous studies in the accounting literature have focused on corporate characteristics to examine managers' incentive to release additional information. However, different measurements of the extent of corporate disclosures and alternative firm characteristics were employed. Earlier studies conducted on determinants of forward-looking (FL) information have concentrated on the earnings forecast as a proxy for FL information. For example, Frankel et al. (1995) used a dichotomous measure indicating whether a company issued earnings forecasts or not in the Dow Jones Retrieval Service of 1880 firm-observations over the years of 1980-1983. They found that earnings forecasts are positively related to the need for external funds and company size. Clarkson et al. (1994) concentrated on forecasts of good news on earnings. They found a positive relationship between the earnings forecast and capitals' needs and corporate size, but negative relationships between the earnings forecasts and the threat of competitors, earnings volatility, and earnings shock. Similar results were found in Australia, by Kent and Ung (2003) who likewise found that larger companies with less volatile earnings were more likely to provide earnings forecasts in their annual reports. 
Miller and Piotroski (2000) instead considered both earnings and sales forecasts, as well as examining more explanatory variables were examined and the results were more informative. Using logistic regression they found that disclosure is positively associated with the following: managers' prior disclosure histories, strong and more persistent earnings news, firms operating in high litigation industries, and strong institutional ownership. Johnson et al. (2001) instead examined the impact of the Private Securities Litigation Reform Act on the disclosure of earnings and sales forecasts for 1064 high technological US firms in 1994 and 1996 and found that the Act increased the number of firms which issued forecasts. However, it also appears that litigation risk is a significant driver of the voluntary disclosure of earnings forecasts and that they are used to help adjust investors' expectations downwards (Skinner, 2004; Kasznik and Lev, 1995)

In contrast, Wasley and $\mathrm{Wu}$ (2006) in a study of the determinants of cash flow forecasts find that cash flow forecasts are more frequently provided when the news is good, and that such cash flow forecasts are used in particular to mitigate the bad news in earnings forecasts or to add credibility to either particularly good earnings forecasts or to forecasts made by younger firms who may have less credibility in the market place. Additionally, the results revealed a positive relationship between management cash flow forecast and earnings volatility, capital intensity, firm size, the existence of analyst cash flow forecasts, and management earnings forecasts. However, the management cash flow forecast is negatively related to Altman's Z-scores.

The current study extends this work and offers a new perspective by considering the disclosure of cash flow information not only in the economic context of the firm but also in its wider social, political and institutional context. Specifically, it argues that the voluntary disclosure of cash flow forecast is subject to two types of influence. The first of these involves managers' incentives to produce relevant information to debt or stock market participants to reduce information asymmetry and agency conflicts (e.g., Lang and Lundholm, 1996; Petersen and Plenborg, 2006; Brown and Hillegeist, 2007). However, while information asymmetry has proved to be successful in explaining many disclosure choices it is only a limited explanation, in that it ignores many other potential influences on behaviour. Specifically, accounting practices, including disclosure decisions, may also be shaped by external factors, in particular institutional 
factors, such that companies operating in a similar environment are faced with similar demands with respect to what may be deemed to be appropriate behaviour. Particularly important here is institutional isomorphism which explains how the environment permeates organisations, including firms, mainly via political and cultural processes (DiMaggio \& Powell, 1983, Moll et $\mathrm{al}, 2006)$

Institutional theory has primarily been to explain organisations' management accounting (Bergevarn et al 1995, Hoque and Hopper, 1994; Modell, 2003) audit practices (Carpenter \& Dirsmith, 1993) and the adoption of particular accounting systems (Carpenter \& Feroz, 1992, 2001; Neu and Ocampo, 2007). While there have been few studies using it to explain disclosure decisions, it has been used to explain certain social responsibility disclosures within the annual reports (Unerman and Bennett, 2004). The theoretical framework applied in this study therefore provides a broader and arguably considerably richer and more informative understanding of the factors affecting managers' decisions to disclose cash flow forecasts.

\subsection{Analyst Following}

Lang and Lundholm (1993) and Botosan (1997) found that firms with more informative disclosures have larger analyst following. Previous research on forward-looking information, such as Walker and Tsalta (2001) and Athanasakou and Hussainey (2009) showed that forwardlooking disclosures are also positively related to a larger analyst following. This may be at least partially because information disclosure makes their task easier, so encouraging them to follow the company. Thus, Bozzolan et al. (2009) for example, found evidence that the disclosure of verifiable financial information increases accuracy and reduces the dispersion of financial analysts' forecasts. Alternatively or in addition, it may be that companies that are under more external scrutiny can reap more benefits from managing the information flows to the market and arguably thereby reduce information asymmetry. However, institutional theory also posits a positive relationship between analyst following and disclosure. For example, Healy and Palepu (2001) argued that financial analysts are viewed as strategy advisors to the company that they are 
analysing and thus are viewed in a manner akin to professional consultants. Based on normative isomorphism in institutional theory, companies will tend to comply with suggestions or recommendations of external institutions including both professional bodies and consultants (DiMaggio and Powell, 1983).

In contrast to the findings that analyst following is related to forward information disclosures, Clarkson et al. (1999), Miller and Piotroski (2000), and Beretta and Bozzolan (2008) found no significant relationship between forward-looking information and analysts followings. However, despite this, based on the above theoretical arguments, it is hypothesised that:

H1: There is a positive association between the voluntary disclosure of cash flow forecasts and analyst following.

\subsection{Industry Behaviour}

Firm behaviour can be influenced by social networks, or by a set of relationships in an industry (Granovetter, 1985). Network relationships distribute norms, values, and procedures as signals, through social groups suggesting the right thing to do (DiMaggio and Powell, 1983). Pfarrer et al. (2008) argued that companies experience network pressure through personnel exchanges, company boards, and sharing the same auditors. Thus, while normative isomorphism suggests that companies might disclose information because they think they should, or that this is a good thing to do so, or because it is suggested by or endorsed by professional bodies, external consultants or others in positions of power or importance, mimetic isomorphism suggests that firms will similarly follow the practices of firms they perceive to be leaders or more successful than themselves. Such behaviour may in turn either help them to gain the same success or prominence or, if not, the firm will be seen by outsiders as following policies that are similarly being carried out by successful firms (Scott, 1995).

Institutional theory thus suggests that the existence of a dominant firm with a high level of disclosure in a particular industry will encourage other firms in the same industry to provide additional information. In other words, organisations follow the internal structures and procedures of other organisations in the same group; and in turn industry patterns emerge with 
some industries typically showing different or higher levels of disclosures than others. (Empirically for example, Haveman (1983) found that organisations imitate other successful organisations (whether these are large or profitable) in the same industry while Botosan and Harris (2000) found that such imitation included the adoption of similar disclosure policies.

Looking more specifically at management cash flow forecasts, Wasley and Wu (2006) found significant and positive relationship between the release of such forecasts and the disclosure practices of other firms in the same industry. Based on the above arguments, and consistently with institutional theory, it can be hypothesised that:

H2A: There is a positive association between voluntary disclosure of cash flow forecasts and industry behaviour.

While mimetic isomorphism suggests that disclosure may exhibit industry specific patterns, disclosure may also be used by a company to signal the fact that it is a leader in the industry. Thus, a second alternative hypothesis is also tested

H2B: There is a positive association between the voluntary disclosure of cash flow forecasts and industry leadership.

\subsection{Change in OFR Regulations}

Based on institutional coercive isomorphism, external factors such as government regulation force organisations to adopt internal structures and procedures (DiMaggio and Powell, 1983). Not only might this alter the costs of any associated voluntary disclosures but organisations may view regulatory pressures as a force or persuasion to confirm expected behaviour (DiMaggio and Powell, 1983; Greening and Gray, 1994) so encouraging them to increase voluntary disclosure.

In considering the relationship between regulated and unregulated disclosures, Dye (1986) taking instead an information asymmetry perspective, modelled various cases, and concluded that mandatory and voluntary disclosures are complement to each other. Dye (1986) theoretically argued that if a company already discloses mandatory information, then the marginal impact on 
competitive advantage from additional information might be reduced. Chow et al. (1996) provided experimental evidence consistent with Dye (1986) while Xiao et al. (2004) pointed out that mandatory disclosure creates a favourable environment and adds credibility to voluntary disclosures so encouraging them.

In regards to the change in FL regulations, the government issued statutory statement in April 2005 which introduced the OFR requirement. All listed companies are required to produce a statutory OFR for the reporting period beginning on or after 1 April 2005. The OFR can be defined as:

"a narrative explanation, provided in or accompanying the annual report, of the main trends and factors underlying the development, performance and position of an entity during the financial year covered by the financial statements and those which are likely to affect the entity's future development, performance and position" [RS: OFR, Para 3] (ASB, 2006).

Thus while the OFR did not mandate the provision of cash flow statements, the requirement to provide information on any trends or factors which likely to affect future performance or position may well have encouraged the voluntary release of cash flow forecasts.

Unfortunately, the government cancelled the mandatory disclosure on 12 January 2006 and issued a statement of best practice, which is intended to have persuasive rather mandatory force. This study focuses on 2004-2006 period, since this time presents an important period of changes in regulation that might affect the level of voluntary disclosure of cash flow forecast information. Thus, consistently with institutional theory and previous studies, it can be hypothesised that:

H3: There is a positive association between the voluntary disclosure of cash flow forecasts and the status of the OFR regulations. 


\subsection{Operating Cash Flows}

Hutton et al. (2003) and Baginski et al. (2004) argued that information asymmetry increased when management earnings guidance ${ }^{1}$ is either above or below the consensus and hence additional disclosure help investors to interpret the news in management's earnings guidance to avoid surprising investors. Hutton et al. (2003) similarly suggested that managers provide additional information to increase the credibility of good earnings news when this is driven by underlying cash flow rather than accounting discretion, while Bhattacharya et al. (2003) and Lougee and Marquardt (2004) found instead that non-GAAP earnings measures are more likely to be produced for firms with bad news.

While Adhikari and Duru (2006) found a positive but insignificant the relation between cash flow to net income ratio and disclosure of free cash flow, Wasley and $\mathrm{Wu}$ (2006) found a significant positive relationship between changes in operating cash flow deflated by lagged total asset and disclosure of a cash flow forecast. Therefore, based on the above discussions and consistent with prior research, a positive relation is expected between cash flows and cash flow information. . It can be therefore hypothesised.

H4: There is positive association between the voluntary disclosure of cash flow forecasts and operating cash flow to lagged assets.

\subsection{Leverage}

Companies with high debt in their capital structure are more likely to disclose additional information to reduce agency cost (Jensen and Meckling, 1976). Disclosures of additional information may act to confirm that they have not violated any conditions of the contract

\footnotetext{
${ }^{1}$ Earnings guidance is referred to the comments management provides about their expectation of the earnings news and that news about competitive effects across firms.
} 
covenant. Foster (1986). This is turn decreasies the borrower's risk of default, in turn reducing the cost of capital (Baiman and Verrecchia, 1996).

Leverage is widely used in prior studies to examine the determinants of corporate disclosure. For example, O’Sullivan et al. (2008), and Aljifri and Hussainey (2007) demonstrated a positive relationship between the leverage ratio and the extent of forward-looking information. Although Celik et al. (2006) and Lim et al. (2007) failed to find any support for this.

However, despite these two papers, based both on information asymmetry theory and prior studies, a positive relationship is hypothesised between disclosure of FL information and leverage. Thus, it can be hypothesised that:

H5: There is positive association between the voluntary disclosure of cash flow forecasts and leverage.

\subsection{Performance}

Singhvi and Desai (1971) highlighted that when the rate of return is high, managers try to disclose more information to support the continuance of their position and remuneration while Ross (1979) hypothesised that companies with good news are more likely to disclose voluntary information. Milgrom (1981) similarly demonstrated that even if disclosures are costless, external users will interpret non-disclosure as implying bad news. Verrecchia (1983) and Dye (1985) support this, finding that managers with good news provide additional information. However, Skinner (1994) and Kaznik and Lev (1995) demonstrated that companies with bad news are more likely to provide additional information in order to enhance accountability and reduce litigation risk. 
Prior studies have used performance as determinant of disclosure of forward-looking information, but with mixed result. For example, Athanasakou and Hussainey (2009) found a negative relationship between performance and the level of forward-looking information. Whereas, Walker and Tsalta, 2001; Kent and Ung (2003), Hossain et al. (2005), and Beretta and Bozzolan (2008) found no relationship, and Bozzolan and Mazzola (2007) found that accuracy of forward-looking information was increased for profitable firm. Therefore, a non-directional hypothesis is examined:

H6: There is an association between the voluntary disclosure of cash flow forecasts and firm performance.

\subsection{Blockholding}

Substantial shareholders are expected to have both the power and the incentives to monitor managers' behaviours (Jensen and Meckling, 1976) so firms with concentred ownership will tend to have less agency costs and less incentive to provide additional information (Cahan and Hossain, 1996). In contrast, Byrd et al. (1992) highlighted that large shareholdings have stronger incentives to monitor managerial behaviour and so may demand more disclosures.

However, prior studies have found mixed results regarding the importance of blockholder as an explanation for voluntary disclosure. McKinnon and Dalimunthe (1993), Mitchell et al. (1995) and Schadewitz and Blevins (1998) found a negative relation between voluntary disclosure and blockholder ownership while Eng and Mak (2003) found no relationship and Hossain et al. (1994) and Hufang and Jianguo (2007) found a positive relationship. 
Similarly previous research on forward-looking information is inconclusive. O'Sullivan et al. (2008) found a positive but insignificant relation between FL information and blockholder ownerships whilst Cahan and Hossain (1996) found a negative. So, based on theory and consistent with previous studies, it can be hypothesised that:

H7: There is an association between the voluntary disclosure of cash flow forecasts and blockholder ownership.

\subsection{Growth opportunities}

Growth companies have greater potential for information asymmetry and they are more likely to reduce information asymmetry through voluntary disclosures (Core, 2001), This has been supported empirically by Hossain and Ahmed (2000).

While Mason and Merton (1985) indicated that growth opportunities consists of new projects, acquisitions of other firms, new brands, replacement of exciting assets and expansion projects, Lev and Stefano (2003) instead believed that the major driver of company's growth opportunities is intellectual capital, which consists of innovation information, communication technologies, networks and alliance, high quality human resources and management processes. Barth et al. (2001) employed the market to book value ratio as a proxy for growth opportunities as this ratio provides a measure of unrecorded intangible assets which in turn are a major determinant of the 
amount of growth opportunities. These companies typically also have a higher amount of information asymmetry (Brown and Hillegeist, 2007).

Hossain et al. (2005) showed that growth opportunities measured by either market to book value of assets and market to book value of equity is positively related to the extent of forward-looking disclosures while O'Sullivan et al. (2008) demonstrated that high growth companies publish more FL information to alleviate information asymmetry and Athanasakou and Hussainey (2009) showed that book to market value is negatively related to voluntary disclosure of forwardlooking information. However, while Cahan and Hossain (1996), Walker and Tsalta (2001) and Eng and Mak (2003) all hypothesised a positive relations between growth opportunities and forward-looking information, but they found no significant evidence.

Despite these insignificant empirical results, it is hypothesised that high growth companies are more likely to provide additional information to indicate their success and management expertise and so maximise shareholder value in the market. It can therefore be hypothesised that:

H8: There is positive association between the voluntary disclosure of cash flow forecasts and growth opportunities.

\subsection{Control variables}

In addition to the relationships hypothesised above, a number of control variables are also employed. The size of the company is measured in terms of sales. Also considered are crosslisting, in particular listing in the USA, the year end and the existence of a profit forecast. Beretta and Bozzolan (2008) documented that the extent of forward-looking information is positively related to a firm's other forms of disclosure. Cao et al. (2007) found that management earnings forecasts and cash flow forecasts support each other by reducing the forecast bias. 


\section{Research Design}

\subsection{Sample}

Table 1 presents the sample construction process. The population consists of the top $500 \mathrm{UK}$ listed firms by total market capitalization as listed by the Financial Times UK 500 on 30 March 2007.. After removing financial and investment companies and AIM companies because of the very different operating or institutional environments they face and missing data, the final sample consists of balanced data of 230 companies $^{2}$ (690 firm-year observations for 2004-2006).

\section{Table 1 Sample Selection Criteria}

\begin{tabular}{|c|c|c|}
\hline & Firms per Year & Firm-Year Observations \\
\hline $\begin{array}{l}\text { Top } 500 \text { UK listed firms by market capitalization } \\
\text { (as listed by Financial Times on } 30 \text { March 2007) } \\
\text { for the 2004-2006 period. }\end{array}$ & 500 & 1500 \\
\hline Financial and Investment companies & 128 & 384 \\
\hline FTSE AIM 100 & 36 & 108 \\
\hline Unavailable in DataStream & 50 & 150 \\
\hline Missing Annual reports & 15 & 45 \\
\hline Problem in annual report conversion ${ }^{3}$ & 11 & 33 \\
\hline Observations with missing financial data & 20 & 60 \\
\hline Outliers & 10 & 30 \\
\hline Total final sample & 230 & 690 \\
\hline
\end{tabular}

\subsection{Variables employed}

One important issue in studies of this type is the issue of how to locate and measure relevant disclosure as typically forward looking information, including cash flow forecasts, are contained in the narrative sections of reports and often are untitled. Thus, most of the previous studies of forward looking disclosures have used relatively small samples, due to the difficulty in

\footnotetext{
${ }^{2}$ The exclusion of a firm in one year for any reason automatically leads to the exclusion of the same firm from the other years.

${ }^{3}$ All annual reports are converted to text files so they are readable by QSR NVivo 8 with the exception of 11 annual reports that could not be converted to text files. In these reports, annual reports are saved as image and when we convert these reports into text files, we got word that are difficult to read either manually or by the computer software.
} 
performing manual content analysis. However, recently, explanatory studies have increasingly employed automated content analysis to score forward looking narratives (Hussainey et al., 2003; Houssainey and Walker 2009; Mouselli et al, 2012; Schleicher et al 2007). A similar approach was taken by Wasley and $\mathrm{Wu}$ (2006) when to measure the incidence of cash flow forecasts. Specifically, they used a keyword search to identify forecasts in press releases. A keyword search was used to find the term 'cash flow' in close proximity to terms such as 'predicts', 'forecasts', 'sees', 'projects', or 'puts' on the Factiva database..

To permit the use of a relatively large sample, the current study similarly employs computerised content analysis using QSR NVivo 8. This not only enables the automation of a large sample of annual reports in a relatively short time but it also reduces the level of subjectivity inherent in manual content analysis. The annual report narrative sections which are considered to be highly standardised, i.e. directors' reports, corporate governance report, remuneration report, list of content, list of directors and advisors, statement of directors' responsibilities, financial history and financial summary, and shareholder information were converted into standard text format files and imported into NVivo. This is consistent with previous studies (e.g., Walker and Tsalta, 2001; Hussainey et al., 2003; Beattie et al., 2004) and leaves the narrative, largely voluntary section, such as, chairman's, CEO's and financial director's statements, operating and financial review, business review or review of the operation, community and people, and environmental report.

A keyword search was used to identify cash flow forecasts in these sections of the annual reports. The disclosure scores are calculated in three steps. The first step requires the identification of text unit with forward-looking keywords. In this step, text-search queries are used to automate the analysis of narrative sections of annual reports using a list of forwardlooking keywords as reported in table 2 .

Table 2 List of Forward-Looking Keywords

\begin{tabular}{|l|l|l|l|}
\hline Number & Keywords & Number & Keywords \\
\hline 1. & Accelerate & 19. & Look forward \\
\hline 2. & Anticipate & 20. & Next \\
\hline 3, & Await & 21. & Near term, medium term \\
\hline 4. & Coming[financial] year[s] & 22. & Optimistic \\
\hline 5. & Coming months & 23. & Outlook \\
\hline
\end{tabular}




\begin{tabular}{|l|l|l|l|}
\hline 6. & Confidence, Confident & 24. & Plan \\
\hline 7. & Convince & 25. & Predict \\
\hline 8. & Future & 26. & Remain \\
\hline 9. & Possible & 27. & Renew \\
\hline 10. & Estimate & 28. & Probable \\
\hline 11. & Aim & 29. & Opportunity \\
\hline 12. & Expect & 30. & Commitment \\
\hline 13. & Forecast & 31. & Further \\
\hline 14. & Forthcoming & 32. & Chance \\
\hline 15. & Hope & 33. & Well placed, Well positioned \\
\hline 16. & Intend, Intention & 34. & Year[s] ahead \\
\hline 17. & Likely, Unlikely & 35. & $2006 / 2007,2006-2007,2006 / 07$ \\
\hline 18. & Look ahead & 36. & $2007,2008 \ldots . .2030$ \\
\hline
\end{tabular}

Hussainey et al.'s (2003) list was used as a preliminary list of forward-looking keywords. This was then modified and potential keywords added based upon an initial manual content analysis of 30 annual reports (for example, "possible", "probable”, “opportunity", "further”, “chance”, "future", "commitment", "near term" and "medium term") while others were instead excluded due to their very low frequency of occurrence (for example, "envisage", "eventual", "novel", "scope for", "scope to", and "shortly"). The next step is the use of text search queries to find cash flow keywords. The final step was performed through the use of advanced coding queries in order to find forward-looking keywords that were, following Waslay and $\mathrm{Wu}$ (2006), within seven words of the cash flow keywords. The disclosure score was then converted to 1 for companies with cash flow forecasts and 0 otherwise, regardless of the number of forecasts or whether they were qualitative or quantitative.

Table 3 shows a list of independent variables as discussed above and their proxies.

Table 3 Independent Variables and their Measures

\begin{tabular}{|c|c|c|}
\hline $\begin{array}{l}\text { Independent } \\
\text { Variables }\end{array}$ & Code & Measures \\
\hline \multicolumn{3}{|c|}{ Institutional Variables } \\
\hline Analyst following & ANFL & $\begin{array}{l}\text { The number of analyst following the company in FACTSET } \\
\text { Excel Connect Database at the end of } t \text {. }\end{array}$ \\
\hline Industry behaviour 1 & INDBEH & $\begin{array}{l}\text { Percentage of other companies in the same industry with a cash } \\
\text { flow forecast in the same year. }\end{array}$ \\
\hline Industry behaviour 2 & LEAD & $\begin{array}{l}\text { A dichotomous variable equal to } 1 \text { if firm } i \text { market share is } \\
\text { above } 1 / \mathrm{N}(\mathrm{N}=\text { number of companies in the industry) and } 0 \\
\text { otherwise }\end{array}$ \\
\hline
\end{tabular}


Change in OFR Reg. REG

Information Asymmetry Variables

Operating cash flow to lagged total assets

Leverage LEV

Performance ROA

Blockholding of $5 \%$

or more

Growth

opportunities

\section{Control variables}

Company size

Cross-listing

Year-end 2004

Year-end 2005

Profit forecasts
$\mathrm{OCF}$

NOSHST

BVMV

Size

CrossList

YearEnd04

YearEnd05

PROFT
A dichotomous variable equal to 1 if the firm $i$ year-ends during changes in OFR regulation (1 April 2005-12 January 2006), and 0 otherwise.

Firm $i$ 's cash in operating activities at the end of $t$ (DS 1015) divided by total assets at the end of $t-1$ (DS 392).

Firm $i$ 's total debt at the end of $t$ (DS 1301) to total assets at the end of $t$ (DS 392).

Firm $i$ 's published after tax profit at the end of $t$ (DS 623) divided by total assets at the end of $t$ (DS 392).

The percentage of total shares in issue held strategically at the end of $t$ (DS NOSHST).

Book value of equity to market value of equity

The natural logarithm of total sales at the end of $t$ (DS 104).

A dichotomous variable equal to 1 if the firm $i$ is cross-listing on the US NYSE or NASDAQ, and 0 otherwise.

A dichotomous variable equals 1 for the 2004 year-end firm observations, and 0 otherwise.

A dichotomous variable equals 1 for the 2005 year-end firm observations, and 0 otherwise

A categorical variable equals to 1 if the firms disclose profit forecasts, either qualitative or quantitative, and 0 otherwise.

\section{The Empirical Results}

\subsection{Descriptive Analysis}

This section reports on the disclosure of cash flow forecasts. Table 3 reports the frequency distribution of cash flow forecasts by year; with 290 cash flow forecasts during the three years, 2004-2006. However, the frequency varies quite considerably, with the least occurring in 2005 $(\mathrm{N}=76,26.2 \%)$, and the most a year later in $2006(\mathrm{~N}=120,41.4 \%)$, when ASB issued a statement of best practice for OFR instead of the compulsory regulation of OFR in 2005. This change affects the audit of the information, as the audit of voluntary information is not as strict 
as the audit of mandatory information. This means that the litigation risk is likely to be less and this may have encouraged the increase in disclosure.

Table 3 Frequency of Cash Flow Forecasts per Year

\begin{tabular}{lll}
\hline Year & $\begin{array}{l}\text { Firms with management } \\
\text { cash flow forecasts }\end{array}$ & $\begin{array}{l}\text { Percentage of firms with } \\
\text { cash flow forecasts }\end{array}$ \\
\hline 2004 & 94 & 32.4 \\
2005 & 76 & 26.2 \\
2006 & 120 & 41.4 \\
\hline Total & 290 & 100 \\
\hline
\end{tabular}

This Table reports on the presence of cash flow forecasts in the narrative sections of annual reports.

Table 4 instead presents the frequency distribution of cash flow forecasts by industry over the study period. Industry definitions are based on the Industry Classification Benchmark system as given by the London Stock Exchange (LSE). The Table presents the proportion of companies with/without cash flow forecasts within each industry across the period of the study.

Table 4. Frequency and Percentage of Disclosing/Non-disclosing Companies by Industry

\begin{tabular}{|c|c|c|c|c|c|}
\hline \multicolumn{6}{|c|}{ Panel (A) 2004} \\
\hline \multirow[t]{2}{*}{ Industry description } & \multirow[t]{2}{*}{ ICB Code } & \multicolumn{2}{|c|}{ Frequency } & \multicolumn{2}{|c|}{ Percentage } \\
\hline & & Disclose & $\begin{array}{c}\text { Non- } \\
\text { disclose }\end{array}$ & Disclose & $\begin{array}{c}\text { Non- } \\
\text { disclose }\end{array}$ \\
\hline Oil and gas & 0001 & 4 & 9 & 31 & 69 \\
\hline Basic material & 1000 & 5 & 4 & 56 & 44 \\
\hline Industrial & 2000 & 31 & 56 & 36 & 64 \\
\hline Consumer good & 3000 & 11 & 10 & 52 & 48 \\
\hline Health care & 4000 & 3 & 8 & 27 & 73 \\
\hline Consumer service & 5000 & 28 & 33 & 46 & 54 \\
\hline Telecommunication & 6000 & 4 & 0 & 100 & 00 \\
\hline Utilities & 7000 & 3 & 5 & 37 & 63 \\
\hline Technology & 9000 & 5 & 11 & 31 & 69 \\
\hline \multicolumn{6}{|c|}{ Panel (A) 2005} \\
\hline \multirow[t]{2}{*}{ Industry description } & ICB Code & \multicolumn{2}{|c|}{ Frequency } & \multicolumn{2}{|c|}{ Percentage } \\
\hline & & Disclose & $\begin{array}{c}\text { Non- } \\
\text { disclose }\end{array}$ & Disclose & $\begin{array}{c}\text { Non- } \\
\text { disclose }\end{array}$ \\
\hline Oil and gas & 0001 & 4 & 9 & 31 & 69 \\
\hline Basic material & 1000 & 2 & 7 & 22 & 78 \\
\hline
\end{tabular}




\begin{tabular}{llcccc}
\hline Industrial & 2000 & 25 & 62 & 29 & 71 \\
Consumer good & 3000 & 8 & 13 & 38 & 62 \\
Health care & 4000 & 2 & 9 & 18 & 82 \\
Consumer service & 5000 & 23 & 38 & 38 & 62 \\
Telecommunication & 6000 & 4 & 0 & $\mathbf{1 0 0}$ & 00 \\
Utilities & 7000 & 4 & 4 & 50 & 50 \\
Technology & 9000 & 4 & 12 & 25 & 75 \\
& \multicolumn{7}{c}{ Panel (A) 2006 } & \multicolumn{4}{c}{ Percentage } \\
Industry description & ICB Code & \multicolumn{2}{c}{ Frequency } & Disclose & Non- \\
& \multicolumn{7}{c}{ Disclose } & Non- & disclose & \multicolumn{2}{c}{31} \\
Oil and gas & 0001 & 9 & 4 & 69 & 56 \\
Basic material & 1000 & 4 & 5 & 44 & 40 \\
Industrial & 2000 & 52 & 35 & 60 & 52 \\
Consumer good & 3000 & 10 & 11 & 48 & 55 \\
Health care & 4000 & 5 & 6 & 45 & 57 \\
Consumer service & 5000 & 26 & 35 & 43 & 25 \\
Telecommunication & 6000 & 3 & 1 & $\mathbf{7 5}$ & 63 \\
Utilities & 7000 & 3 & 5 & 37 & 50 \\
Technology & 9000 & 8 & 8 & 50 & \\
\hline
\end{tabular}

This shows some quite major industry differences. Thus, for example, in 2004 and 2005 all the telecommunications companies disclose forecast information. While only one-third or less of companies in the oil and gas and technology industries report forecast information in the same period.

\subsection{Multiple Regression Analysis}

Pooled logistic regression analysis is conducted using the Limdep 7 econometric software package (Greene, 1995) in order to investigate the factors that affect managers' decisions to voluntarily disclose cash flow forecasts among UK non-financial companies. However, before conducting the regression analysis, the data set must comply with the necessary assumptions; in particular there should be no multicollinearity or heteroscedasticity. Field (2005) suggested simply running a linear regression analysis using the same outcome and predictors to obtain the VIF to check for a multicollinearity problem. The VIF values for all independent variables are less than 3.0, implying there is no problem. However, the leadership variable resulted in a significant problem of heteroscedasticity. Following Williams (2009), the study therefore used 
the "Heteroscedastic Logit Model for Binary Data" in order to correct for this problem, as presented in Table 5.

The pooled logistic regression model is as follows:

$\mathrm{CF}=\beta 0+\beta 1 \mathrm{ANFL}+\beta 2 \mathrm{~A} \mathrm{INDBEH}+\beta 2 \mathrm{~B} \mathrm{LEAD}+\beta 3 \mathrm{REG}+\beta 4 \mathrm{OCF}+\beta 5 \mathrm{LEV}+\beta 6 \mathrm{ROA}+$ $\beta 7$ NOSHST $+\beta 8$ BVMV $+\beta 9$ size $+\beta 10$ CrossList $+\beta 11$ YearEnd04 $+\beta 12$ YearEnd05 $+\beta 13$ PROFT $+\mathrm{e}$

Where: $\mathrm{CF}=$ disclosure of cash flow forecast, $0=$ no disclosure, $1=$ disclosure; ANFL = analyst following; INDBEH = industry behaviour; LEAD = leadership; REG= change in OFR regulation; OCF = operating cash flow; LEV = leverage; $\mathrm{ROA}=$ performance; NOSHST = blockholding of $5 \%$ or more; BVMV = book value to market valueSize = company size; ; CrossList $=$ cross-listing; YearEnd04 $=$ year-end in 2004; YearEnd05 $=$ year-end in 2005; PROFT $=$ profit forecast; $\mathrm{e}=$ error term. 
Table 5. Heteroscedastic Logit Model for Binary Data

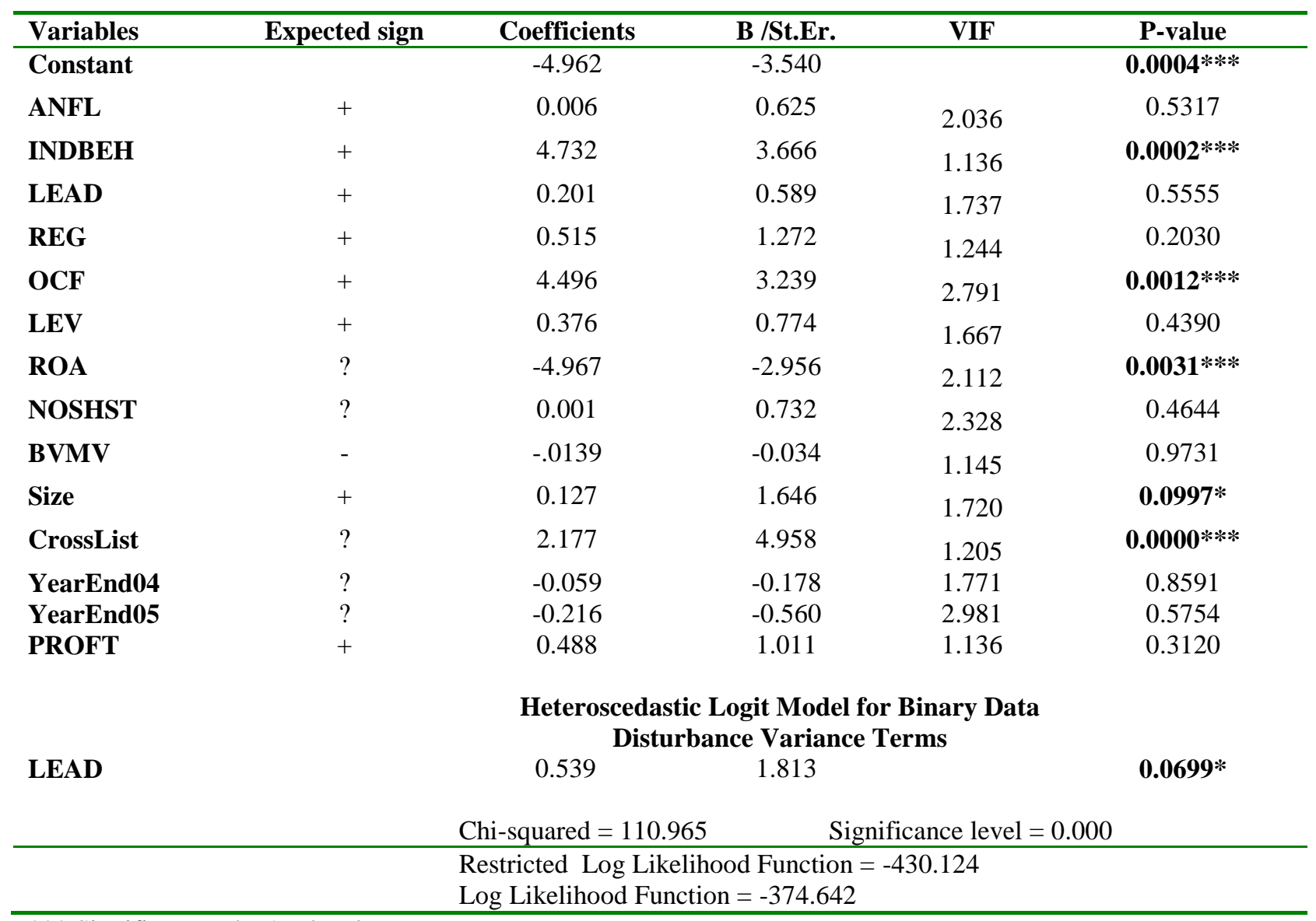

*** Significant at the $1 \%$ level

** Significant at the 5\% level

* Significant at the $10 \%$ level

The model is highly significant $\left(\chi^{2}=110.97 \mathrm{P}-\right.$ Value $\left.=0.000\right)$, with industry behaviour, OCF regulation, performance or ROA, and cross listing all significantly related (at $1 \%$ ) to voluntary disclosure of cash flow forecast. ,

The result of pooled logistic regression documents, as predicted, industry behaviour is positively and significantly consistent with mimetic isomorphism in that companies try to copy the disclosure practices of other companies in the same industry. This result is also consistent with Wasley and $\mathrm{Wu}$ (2006). The profit forecast, $(\mathrm{B}=1.011)$, while of the correct sign, is insignificantly related to the disclosure of cash flow forecasts. This result is inconsistent with previous studies which document a positive relationship between FL information and a firm's 
other forms of disclosure (e.g., Wasley and Wu, 2006; Cao et al., 2007; Beretta and Bozzolan, 2008).

Additionally, the results presented in Table 6 show that performance $(B=-2.956)$ is negatively and significantly related to voluntary disclosure of cash flow forecast, suggesting that companies disclose good news in cash to mitigate the negative impact of bad news in earnings. This result is also consistent with Wasley and Wu (2006) and Adhikari and Duru (2006). In addition, OCF (B $=3.239$ ) is positively and significantly related to cash flow forecast. This result is inconsistent with institutionalism in that it was expected that increased regulation mighth also encourage increased voluntary information. However, it does suggest that litigation risk might instead be important.. Also, the result indicates a positive and significant relationship between the control variables of both company size and cross-listing variables and cash flow forecast at the $10 \%$ level and the $1 \%$ level, respectively.

Additional regression models are performed using different proxies for independent variables in order to ensure that multivariate results are robust to a different combination of independent variables proxies. In short, sensitivity and additional analyses identify quite similar inferences to the primary regression analysis model; this confirms the robustness of the regression results.

\section{Conclusion and Implications}

The objective of this study was to examine the determinants of the issuance of voluntary management cash flow forecasts over the period 2004-2006. Automated content analysis using QSR NVivo 8 is used to find the cash flow forecasts in voluntary sections of annual reports. The results show that there has been an increase in the issuance of cash flow forecasts for the year 2006, when ASB issued a voluntary statement of best practice for OFR regulation instead of the compulsory regulation in 2005. This implies that behaviour is influenced by the cost of violation of statuary regulation which results in a higher litigation risk, leading to the disclosure of less forward looking information. 
The result of pooled logistic regression model reveals that agency theory explanations of corporate behaviour can be usefully supplemented by consideration of the social, political and market environment in which the corporation operates. Specifically here, industry behaviour is an important factor in explaining managers' incentives to disclose cash flow forecasts, which is consistent with mimetic isomorphism, as institutional theory suggests. Furthermore, the results document that disclosure of cash flow forecasts is positively and significantly related to operating cash flow, but it is negatively and significantly related to performance and competition rate. Furthermore, corporate size and cross-listing are found to be positively and significantly related to disclosure of cash flow forecasts. This result implies that cash flow forecasts are subject to alternative proxies of information asymmetry and institutional characteristics.

Our findings have important implications. It helps to inform regulators the incentives for issuing cash flow forecasts by UK firms. This information is needed when studying the cost-benefit analysis of increased disclosures. In addition, our paper has important implications for academic research. It produces a new method for calculating cash flow forecasts in annual report narratives. Researchers can follow our method and then study the economic consequences of cash flow forecasts disclosures in the annual report narratives. Finally, in order to increase our understanding of institutional characteristics, future research could be conducted to determine the variability in cash flow forecasts across different European countries, since country factors as well as legal and regulatory authorities may play an important role in determining reporting practices due to differences in litigation risk between countries. 


\section{References}

Accounting Standards Board (ASB) (2006), Reporting Statement (RS): Operating and Financial Review, (London, ASB).

Adhikari, A. and Duru, A. (2006), "Voluntary disclosure of free cash flow information", Accounting Horizons, Vol. 20, No. 4, pp.311-332.

Aljifri, K. and Hussainey, K. (2007), "The determinants of forward-looking information in annual reports of UAE companies", Managerial Auditing Journal, Vol. 22, No. 9, pp. 881-894.

Athanasakou, V. and Hussainey, K. (2009), "Do investors rely on forward-looking earnings statements? The Role of Forecasting Reputation and Earnings Quality", November, Working Paper.

Baginski, S. P., Hassell, J. M. and Kimbrough, M. D. (2004), "Why do managers explain their earnings forecasts?", Journal of Accounting Research, Vol. 24, No. 1, PP. 1-29.

Barth, M. E., Kasznik, R., and McNichols, M. F. (2001), "Analyst coverage and intangible assets", Journal of Accounting Research, Vol. 39,1: 1-34.

Beattie, V. A. (2000), "The future of corporate reporting: a review article", Irish Accounting Review, Vol 7, No. 1, pp.1-36.

Beattie, V., McInnes, B. and Fearnley, S. (2004), "A methodology for analysing and evaluating narratives in annual reports: A comprehensive descriptive profile and matrices for disclosure quality attributes", Accounting Forum, Vol. 28, pp.205-236.

Beretta, S. and Bozzolan, S. (2008), "Quality versus quantity: the case of forward-looking disclosure", Journal of Accounting, Auditing and Finance, Vol. 23, pp.333-375.

Bergevarn L.E., Mellemvik, F. and Olson, O. (1995) "Institutionalism of municipal accounting: a comparative study between Sweden and Norway", Scandinavian Journal of Management, Vol. 11, No.1, pp.25-41 
Bhattacharya, N., Black, E. L., Christensen, T. E. and Larson, C. R. (2003), "Assessing the relative informativeness and permanence of pro forma earnings and GAAP operating earnings", Journal of Accounting and Economics, Vol. 36, pp.285-319.

Botosan, C. A. (1997), "Disclosure level and the cost of equity capital", The Accounting Review, Vol. 72, No. .3, pp.323-349.

Botosan, C.A. and Harris, M. S. (2000),'Motivations for change in disclosure frequency and its consequences: an examination of quarterly segment disclosures", Journal of Accounting Research, Vol. 38, pp.329-353.

Bozzolan, S. and Mazzola, P. (2007), "Strategic plan presentations to financial analysts: the effects on earnings forecasts' revision and cost of capital", Working Paper, July. Available at SSRN: http://ssrn.com/abstract=999506.

Bozzolan, S., Trombetta, M. and Beretta, S. (2009),'Forward-looking disclosures, financial verifiability and analysts' forecasts: a study of cross-listed European firms", European Accounting Review, Vol. 18, No. 3, pp.435-473.

Brown, S. and Hillegeist, S. L. (2007), "How disclosure quality affects the level of information asymmetry”, Review Accounting Studies, Vol. 12, pp.443-477.

Byrd, J. W. and Hickman, K. A. (1992), "Do outside directors monitor managers? evidence from tender offer bids", Journal of Financial Economics, Vol. 32, pp.195-221.

Cahan, S. F., and Hossain, M. (1996),"The investment opportunity set and disclosure policy choice: some Malaysian evidence", Asia Pacific Journal of Management, Vol. 13, No. 1, pp.6585.

Cao, Y. Wasley, C. E. and Wu, J. S. W. (2007), "Soft-talk management cash flow forecasts: verifiability, creditability and stock price effects", Working Paper, Simon School, University of Rochester, December.

Carpenter, B. and Dirsmith, M. (1993), "Sampling and the abstraction of knowledge in the auditing profession: an extended institutional theory perspective", Accounting, Organizations and Society, Vol. 18, pp.41-63.

Carpenter, V.L. and Feroz, E.H. (2001), "Institutional theory and accounting rule choice: an analysis of four US state governments' decisions to adopt generally accepted accounting principles", Accounting, Organizations and Society, Vol. 26, pp.565-596.

Celik, O., Ecer, A. and Karabacak, H. (2006), "Disclosure of forward-looking information: evidence from listed companies on Istanbul Stock Exchange (ISE)", Investment Management and Financial Innovations, Vol. 3, No. 2, pp.197-216. 
Chow, C. W., Haddad, K. and Hirst, M. (1996), “An experimental market's investigation of discretionary financial disclosure", Abacus, Vol. 32, No. 2, pp. 133-152.

Clarkson, P. M., Kao, J. L., and Richardson, G. D. (1994),'The voluntary inclusion of forecasts in the MD \& A section of annual reports", Contemporary Accounting Research, Vol. 11, No. 1, pp. 423-450.

Clarkson, P. M., Kao, J. L., and Richardson, G. D. (1999),'Evidence that management discussion and analysis (MD\&A) is a part of a firm's overall disclosure package", Contemporary Accounting Research Vol. 16, No.1, pp.11-35.

Core, J. (2001), "A review of the empirical disclosure literature: Discussion", Journal of Accounting and Economics, Vol. 31, pp.441-456.

DiMaggio, P. and Powell, W. (1983), "The Iron Cage revisited: institutional isomorphism and collective rationality in organisational fields", American Sociological Review, Vol. 48, pp.147160.

DiMaggio, P. and Powell, W. (1991), "Introduction", in Powell, W. and DiMaggio, P. (eds.), The New Institutionalism in Organizational Analysis, The University of Chicago Press, London, pp.1-38.

Dye, R. A. (1986), "Proprietary and non-proprietary disclosures", Journal of Business, Vol. 59, No. 2, pp.331-366.

Eng, L. L., and Mak, Y. T. (2003), "Corporate governance and voluntary disclosure", Journal of Accounting and Public Policy, Vol. 22, pp.325-345.

Field, A. (2005), Discovering Statistics Using SPSS, Second Edition, SAGE Publications, London.

Foster, G. (1986), Financial Statement Analysis, Prentice-Hall, Englewood Cliffs, New Jersey.

Frankel, R., McNicholls, M. and Wilson, G. P. (1995), "Discretionary disclosure and external financing", The Accounting Review, Vol. 70, pp.135-150.

Granovetter, M. (1985), "Economic action and social structure: the problem of embeddedness", American Journal of Sociology, Vol. 91, pp.481-510.

Greene, W. H. (1995), LIMDEP: User's Manual (Version 7.0), Econometrics Software, Bellport, New York.

Greening, D. W. and Gray, B. (1994), "Testing a model of organizational response to social and political issues", Academy of Management Journal, Vol. 45, pp.509-525. 
Haveman, H. (1983), "Follow the leader, mimetic isomorphism, and entry into new markets", Administrative Science Quarterly, Vol. 38, pp.593-627.

Healy, P. and Palepu, K. (2001), "Information asymmetry, corporate disclosure, and the capital markets: a review of the empirical disclosure literature", Journal of Accounting and Economics, Vol.31, pp.405-440.

Hossain, M., Ahmed, K. and Godfrey, J. M. (2005),'Investment opportunity set and voluntary disclosure of prospective information: a simultaneous equations approach", Journal of Business Finance and Accounting, Vol.32, No.5/6, pp.871-907.

Hoque, Z. and Hopper, T. (1994), "Rationality, accounting and politics: a case study of management control in a Bangladesh jute mill", Management Accounting Research, Vol.5, pp.530 .

Hossain, M. and Ahmed, K. (2000), "The effect of growth opportunities on audit fees: evidence from an emerging market”, International Journal of Business Studies, Vol.8, No.37-53.

Huafang, X. and Jianguo, Y. (2007), “Ownership structure, board composition and corporate voluntary disclosure: evidence from listed companies in China", Managerial Auditing Journal, Vol.22, pp.604-619.

Hussainey, K., Schleicher, T. and Walker, M. (2003), "Understanding large-scale disclosure studies when AIMR-FAF ratings are not available: the case of prices leading earnings", Accounting and Business Research, Vol. 33, No.4, pp.275-294.

Hussainey, K. and Walker, M. (2009), "The effects of voluntary disclosure and dividend propensity on process leading earnings", Accounting and Business Research, Vol.39, No.1, pp.37-55.

Hutton, A. P., Miller, G. S. and Skinner, D. J. (2003), “The role of supplementary sentiments with management earnings forecasts", Journal of Accounting Research, Vol.41, No.5, pp.867890.

Jensen, M. C. and Meckling, W. H. (1976), "Theory of the firm: managerial behaviour, agency costs and ownership structure", Journal of Financial Economics, Vol. 3, pp.97-118.

Johnson, M. F., Kasznik, R. and Nelson, K. K. (2001), “The impact of securities litigation reform on the disclosure of forward-looking information by high technology firms", Journal of Accounting Research, Vol.39, No.2, pp.297-327.

Kaznik, R. and Lev, B. (1995), "To warn or not warn: management disclosures in the face of an earnings surprise", The Accounting Review, Vol.70: pp.113-134. 
Kent, P. and Ung, K. (2003),'Voluntary disclosure of forward-looking earnings information in Australia", Australian Journal of Management, Vol.28, No.3, pp.273-286.

Lang, M. and Lundholm, R. (1993), "Cross-sectional determinates of analysts' ratings of corporate disclosures”, Journal of Accounting Research, Vol.31, No.2, pp.246- 271

Lang, M. and Lundholm, R. (1996), "Corporate disclosure policy and analyst behaviour", The Accounting Review, Vol.71, No. 4, pp.467-492.

Lev, B. and Stefano, Z. (2003), "Intangibles and intellectual capital: an introduction to a special issue", European Accounting Review, Vol. 12, pp.597-603.

Lim, S., Matolcsy, Z. and Chow, D. (2007), "The association between board composition and different types of voluntary disclosure", European Accounting Review, Vol.16, No.3: pp.555583.

Lougee, B. A. and Marquardt, C. A. (2004), "Earnings informativeness and strategic disclosure: an empirical examination of "pro forma" earnings", Accounting Review, Vol. 79, No.3, pp.769798.

Mason. S.P. and Merton, R.C. (1985), "The role of contingent claims analysis in corporate finance", in: E.I. Altman. (ed)., Recent Advance in Corporate Finance (Irwin, Homewood. IL).

McKinnon, J. L. and Dalimunthe, L. (1993), "Voluntary disclosure of segment information by Australian diversified companies", Accounting and Finance, Vol. 31, pp.33-50.

Milgrom, P. (1981), “Good news and bad news: representation theorems and applications", Bell Journal of Economics, Vol. 12, pp.380-391.

Miller, G. S. and Piotroski, J. D. (2000),'Forward-looking earnings statements: determinants and market response", Working paper. , July. Available at SSRN: http://ssrn.com/abstract=238593

Mitchell, J.D., Chia, C.W.L. and Loh, A.S. (1995), "Voluntary disclosure of segment information: further Australian evidence", Accounting and Finance, Vol. 35, No.2, pp1-16.

Modell, S. (2003), "Goals versus institutions: the development of performance measurement in the Swedish university sector”, Management Accounting Research, Vol. 14, pp.333-359.

Moll, J., Burns, J. and Major, M. (2006), "Institutional Theory", in Hoque, Z. (ed.) Methodological Issues in Accounting Research: Theories and Methods, Spiramus, London, pp.183-205.

Mouselli, S., Jaafar, A. and Hussainey, K. (2012), “Accruals quality vis-à-vis disclosure quality: substitutes or complements?”, British Accounting Review, Vol.44, pp.36-46. 
Neu, D. and Ocampo, E. (2007), "Doing missionary work: the World Bank and the diffusion of financial practices", Critical Perspectives on Accounting, Vol. 18, No.3, pp.363-389.

O’Sullivan, M., Percy, M. and Stewart, J. (2008), “Australian evidence on corporate governance attributes and their association with forward-looking information in the annual report", Journal of Management and Governance, Vol. 12. No. 1, pp.5-35.

Petersen, C. and Plenborg, T. (2006), "Voluntary disclosure and information asymmetry in Denmark", Journal of International Accounting, Auditing and Taxation, Vol.15. pp.127-149.

Pfarrer, M. D., Smith, K. G., Bartol, K. M., Khanin, D. M. and Zhang, X. (2008), "Coming forward: the effects of social and regulatory forces on the voluntary restatement of earnings subsequent to wrongdoings", Organization Science, Vol. 19, No.3, pp.386-403.

Robb, S. W. G., Single, L. E. and Zarzeski, M. T. (2001), "Nonfinancial disclosures across Anglo-American countries", Journal of International Accounting, Auditing and Taxation, Vol. 10: pp.71-83.

Ross, S. (1979), "Disclosure regulation in financial markets: implications of modern finance theory and signalling theory", in Edwards, f. (ed.), Issue in Financial Regulation, McGraw-Hill. New York, pp.177-202

Schadewitz, H.J. and Blevins, D.R. (1998), "Major determinants of interim disclosures in an emerging market", American Business Review, Vol. 16, No. 1, pp.41-55.

Schleicher, T. and Walker, M. (1999), "Share price anticipation of earnings and managements discussion of operations and financing", Accounting and Business Research, Vol. 29, No. 4, pp. 321-35.

Scott, W. (1995), Institutional and Organisations, Sage Publishing, London.

Singhvi, S. S. and Desai, H. B. (1971), "An empirical analysis of the quality of corporate financial disclosure”, Accounting Review, Vol. 46, No. 1, pp.129-138.

Unerman, J. and Benerr, M. (2004), "Increased stakeholder dialogue and the internet: towards greater corporate accountability or reinforcing capitalist hegemony?", Accounting, Organizations and Society, Vol. 29, pp.685-707.

Vanstraelen, A., Zarzeki, M. T. and Robb, S. W. G. (2003),'Corporate nonfinancial disclosure analyst forecast ability across three European countries", Journal of International Financial Management and Accounting, Vol. 14, No. 3, pp. 249-278.

Verrecchia, R. (1983), "Discretionary disclosure", Journal of Accounting and Economics, Vol. 5, pp.365-380. 
Walker, M. and Tsalta, A. (2001), Corporate Financial Disclosure and Analyst Forecasting Activity: Preliminary Evidence for the UK, ACCA Research Report, No. 67.

Wasley, C. E. and Wu, J. S. (2006),'Why do managers voluntarily issue cash flow forecasts?", Journal of Accounting Research, Vol. 44, No. 2, pp.389-429.

Williams, R. (2009), "Using heterogeneous choice models to compare logit and probit coefficients across groups.' Sociological Methods \& Research, Vol. 37, pp.531-559.

Xiao, J. Z., Yang, H. and Chow, C. W. (2004), "The Determinants and Characteristics of Voluntary Internet-based Disclosure by Listed Chinese Companies", Journal of Accounting and Public Policy, Vol. 23, No. 3, pp.191-225. 